\title{
A Survey Study on the Profile of Human Smugglers in Turkey
}

\author{
Tülin Günşen İçli1, Hanifi Sever², Muhammed Sever ${ }^{3}$ \\ ${ }^{1}$ Sociology Department, Hacettepe University, Ankara, Turkey \\ ${ }^{2}$ Turkish National Police, Graduate School of Social Sciences, Bülent Ecevit University, Zonguldak, Turkey \\ ${ }^{3}$ Graduate School of Social Sciences, Hacettepe University, Ankara, Turkey \\ Email: ticli@hacettepe.edu.tr, hanifisever@yahoo.com, muhammed.sever@gmail.com
}

Received 3 November 2014; revised 20 December 2014; accepted 31 December 2014

Copyright (C) 2015 by authors and Scientific Research Publishing Inc.

This work is licensed under the Creative Commons Attribution International License (CC BY).

http://creativecommons.org/licenses/by/4.0/

(c) (i) Open Access

\begin{abstract}
Illegal migration is an impalpable phenomenon with complicated dimensions. Thousands of people leave their homelands every year due to a number of reasons such as civil wars, terrorism, economic difficulties, and social oppressions. With their flexible modus operandi, migrant smugglers benefit from individuals or groups that wish to immigrate for a more comfortable life. In order to reach a complete perception of illegal migration one needs to draw an accurate profile of migrant smugglers. At this end, data collection from both smugglers as perpetrators and illegal migrants as the object of the smuggling process provides important information for a holistic definition of "smugglers". In this study researchers interviewed 262 illegal migrants and 174 smugglers captured in Istanbul from 2007 to 2013 in order to identify and develop a profile of migrant smugglers and understand the operating methods of illegal migration organizations. The collected data were analyzed and important results on illegal migrant smugglers were reached.
\end{abstract}

\section{Keywords}

Irregular Migration, Irregular Migrant, Migrant Smuggling, Migrant Smugglers

\section{Introduction}

There are a number of occasions in the world (i.e. economic inequality, unsafe environment, political instability, and terrorism) that lead people to migrate in order to have better living conditions or only to save and maintain their lives. Following the collapse of the USSR, new nation-states were established in Eurasia. Due to the poor economic and political standards in these countries, their citizens caused migration flows towards western European countries. In addition, many Asians and Africans migrate legally or illegally to developed countries with 
high standards in order to have better life conditions. Within this concept, illegal or irregular migration can be defined as "migration movements which are not consistent with the regulations and laws of transit and hosting countries" (IOM, 2009: p. 15).

Since economic problems and social matters such as starvation, wars, terrorism and strict custom practices have not been permanently and globally solved yet, migration remains a significant problem which organized crime syndicates exploit and target "helpless migrants". People who want to enter the US and western European countries through illegal ways pay high amounts of money which provides organized crime syndicates to gain high levels of financial profits (Roth, 2010: p. 18).

The aim of this study is to draw a profile of smugglers, and determine their behaviors towards migrants, their socio-demographical characteristics and perspectives about illegal migration.

\section{Literature Review on Migrant Smugglers}

Since they do not possess detailed knowledge about the migration process, illegal migrants cannot provide comprehensive information about smugglers (Neske, 2006: p. 130). In addition, migrants from different backgrounds could have different perceptions of smugglers (Webb \& Burrows, 2009). At this end, illegal migrants' views on smugglers would partially be helpful in profiling migrant smugglers. With regard to nature of crime, the relationship between smugglers and migrants is different from that between criminals and their victims (Van Liempt \& Doomernik, 2006). A research indicates that there is a relation between smugglers and migrants, which is completely commercial and based on trust (Batsyukova, 2012). In various studies migrant smugglers describe themselves as "service providers" than criminals (Staring, 2003; Zhang, Chin, \& Miller, 2007; Soudijn \& Kleemans, 2009). The 2010 report published by the UN Office of Drugs and Crime (UNODC) states that some of the migrant smugglers illegally took African pregnant women to Spain or France to help them for free birth (UNODC, 2010).

The current literature includes a considerable number of studies focusing illegal migrants. Researches on migrant smugglers on the other hand seem to be relatively fewer. Soudjin (2006) examined 88 cases involving 172 individuals who committed migrant smuggling and found that $13 \%$ of migrant smugglers were females and all migrant smugglers had significant roles in international migration organizations. Among 172 migrant smugglers, 22 were organizers, 88 carriers, 2 fake passport providers, 3 public servants and 43 suppliers.

Zhang \& Chin (2002) carried out a study with a sample of 129 migrant smugglers. They found that the original occupations of the migrant smugglers were ordinary professions such as restaurant owners, barbers and waiters (while some of them were unemployed). The majority of them was between 30 and 40 years and had a high school education. Their common desire was to earn more money. In their subsequent study, Zhang \& Chin (2004) concluded that migrant smugglers had very different occupational backgrounds (specifically 70 distinct occupations), including housewives, tailors, taxi drivers, etc. The findings of the study revealed that smugglers were mostly men (82\%) with university education (90\%), married (78\%), and in their thirties (79\%). In addition, $64 \%$ of the smugglers had been in the US since 1993 or before, $63 \%$ entered the country legally, and more than two-thirds were either US citizens or "Green Card" holders. Nearly all of the smugglers (92\%) stated that their motivation was to earn money.

Webb and Burrows (2006) analyzed the relation between smugglers and migrants, therefore interviewed 45 smugglers in the UK prisons. $85 \%$ of the smugglers were men, average age was 35 , and most of them were from Albania and the UK. There were also smugglers from China, Southeast Asia, former Soviet countries, India and Africa. According to the findings of the study, $72 \%$ of the smugglers stated that their motivation was all of a humanitarian reason, as assisting people in their attempt to stay in the UK. All participants of the sample were ordinary working people such as tourism agency workers or market employees. Another study carried out in Italy (Pastore, Monzini, \& Sciortino, 2006) proved that smugglers have ordinary occupations. Almost all of them were Italian and involved in other types of smuggling activities, too. In addition, this study showed that migrant smugglers had extensive knowledge on border security, residing of foreigners and work permits. Hamood (2006) stated that some corrupt white collar employees were also found helping migrant smugglers.

A study on migrant smuggling in Africa (Horwood, 2009) indicates that the ages of migrant smugglers vary from 18 to 40. They were mostly male Somalians or Ethiopians. UNODC reports that Indian migrant smugglers were mostly between 31 and 50 ages and were residing in luxury neighborhoods of the city. They became smugglers because of such economic advantages (UNODC, 2011). 
A research on organized crime depicts that migrant smugglers prefer to employ safe houses. Organized crime groups realize that illegal migration through false passports is among mafia organizations (Leman \& Janssens, 2006). İçduygu \& Toktaş (2002) concluded that Turkish migrant smugglers describe their illegal activities as an ordinary occupation like medicine or engineering which are regular parts of economy and daily life. In another study carried out in France (Courau, 2003), it was found that migrant smugglers are part of mafia-like organizations and they were based in England while their organization had branches in Afghanistan, Albania, Iran and Iraq.

Narli (2006) collected data in Istanbul for eighteen months and one of her significant findings is that migrant smugglers are in cooperation with both crime organizations and terrorist groups. Similarly, Çınar (2010) concluded that one of such terrorist groups in Turkey, PKK, is in close cooperation with migrant smuggling organizations and that migrants are forced to be a member of the terrorist group to increase financial support. A report of the UNODC (2011) stated that some of the migrant smugglers in Africa were the former intelligence agents and policemen. It was further indicated that some them owned small-scale enterprises. There were also those who were involved in other types of smuggling activities and those who were part of terrorist organizations.

Migrant smugglers earn high levels of income due to their activities. This income may become much higher because of tightened border controls, additional security measures and other interventions of the states against migrant smuggling (Cornelius, 2005; Lee, 2005).

\section{Methodology}

The primary data of the study were collected through interviews and questionnaires applied to 174 migrant smugglers who were detained from 2007 to 2013 in Istanbul and 262 illegal migrants (Pakistanis, Afghans and Bangladeshis) who were arrested in June-August 2008 in the same city. The data gathered from these two groups (smugglers and migrants) provides mutual and supplemental information for the study. In addition, a questionnaire was applied to these 262 migrants. 13 items in the questionnaire were determined based on literature review. Before questionnaire, we interviewed all migrants to understand their background. While applying questionnaires to migrants and during interviews with both smugglers and migrants, six interpreters were used. There were no female participants.

\section{Findings}

Table 1 indicates that $66.8 \%$ of the participants (175 individuals) migrated illegally due to economic reasons, $17.6 \%$ (46 individuals) due to security reasons and $15.6 \%$ (41 individuals) due to both reasons. The motivation of illegal migrants was found to vary. While $26 \%$ (68 individuals) decided to migrate illegally due to their contacts in foreign countries (it becomes $34.1 \%$ (89 individuals) when their contacts include friends and relatives in foreign countries) on one hand, $23.3 \%$ (61 individuals) on the other decided to migrate illegally with regard to their friends in home countries. It was also found that 17.9\% (47 individuals) were motivated to migrate illegally by their spouses. Media was also found to be a source of motivation of 18 illegal migrants. When it comes to entrance to Turkey, $85.5 \%$ of illegal migrants (224 individuals) entered from mountains in the eastern border of the country and $14.1 \%$ (37 individuals) entered by sea.

Table 2 indicates that more than half of the migrants $(66 \% ; 173$ individuals) made contacts with smugglers in their native countries and three-fourth of them $(76.3 \%$; 200 individuals) made agreements for illegal migration for an amount of more than $\$ 5000$. The mean amount for such agreements is found to be $\$ 7107.44 \pm \$ 2778.58^{1}$. It was also found that $90.8 \%$ (238 individuals) gave smugglers more than $\$ 1000$ in the names of guarantee money, deposit or agreement money. The participants were found to pay either no money or a maximum of $\$ 10,000$. The mean amount paid was $\$ 3070.03 \pm \$ 1353.18$. Having asked that how they paid the smugglers, it was found that $33.6 \%$ of the participants ( 88 individuals) gave their previously saved money, $26 \%$ (68 individuals) got into debt and 22.5\% (59 individuals) sold their properties.

With regard to the behavior of human smugglers, 62 of the illegal migrants reported that they remained under heavy pressure from the smugglers in different aspects. For instance $75.8 \%$ of migrants (47 individuals) stated that the smugglers exhorted them to say they were from 'Mauritania or Burma if they would be arrested by Turkish security officials. The participants also stated that they got to know four (31.3\%; 82 individuals) or five smugglers (34\%; 89 individuals) during migration.

${ }^{1}$ Illegal migrants reported that they signed an agreement in this process. 
Table 1. Findings collected from illegal migrants.

\begin{tabular}{ccc}
\hline Reason for migration & n & \% \\
\hline Safety & 46 & 17.6 \\
Economic reasons & 175 & 66.8 \\
Both safety and economic reasons & 41 & 15.6 \\
Total & 262 & 100.0 \\
Trigger for migration & $\mathbf{n}$ & $\mathbf{\%}$ \\
\hline Friends in home country & 61 & 23.3 \\
Partner & 47 & 17.9 \\
Friends in foreign countries & 68 & 26.0 \\
Relatives in home country & 20 & 7.6 \\
Friends in home country & 3 & 1.1 \\
Media & 18 & 6.9 \\
Friends in foreign country & 13 & 5.0 \\
Relatives in foreign country & 8 & 3.1 \\
Himself & 24 & 9.2 \\
Total & 262 & 100.0 \\
Ways to enter to Turkey & $\mathbf{n}$ & $\mathbf{\%}$ \\
From mountains illegally & 224 & 85.5 \\
Border crossing & 1 & 0.4 \\
From sea illegally & 37 & 14.1 \\
Total & 262 & 100.0 \\
\hline
\end{tabular}

Views on illegal migration.

According to Table 3, illegal migrants described smugglers as aggressive and rude (35.9\%; 94 individuals), violent (31.7\%; 83 individuals), expert $(13 \% ; 34$ individuals), in panic $(9.5 \% ; 25$ individuals), and well-meant $(9.5 \% ; 25$ individuals). They described those smugglers that helped them in entering the borders and in their trip as aggressive and rude $(53.1 \%$; 139 individuals), no description (35.5\%; 94 individuals) and physically violent $(11.1 \% ; 29$ individuals).

Majority of the illegal migrants reported their fear of dying in their attempt to migrate $(95 \%$; 249 individuals). 113 illegal migrants among them (45.4\%) were threatened or experienced physical violence when they wanted to return to their country whereas $68(27.3 \%)$ of them did not think about returning since they thought they had nothing to lose. Concerning future plans, 143 illegal migrants (54.6\%) reported that they would find a job in the host country through their friends. There were also those who would find a job through their own attempts ( $16 \%$ (42 individuals)) and through migrant smugglers (15.3\%; 40 individuals).

All migrant smugglers, detained by the police are male. In terms of age, $41.4 \%$ ( 72 individuals) of the smugglers are from 30 to 39 years old, while $30.5 \%$ (53 individuals) are from 19 to 29 years. Only seven migrant smugglers $(4 \%)$ were under 18 years. Nearly three fourths of them were married $(72.4 \%)$. Considering educational background, $91.4 \%$ of the smugglers (159 individuals) had primary school education or illiterate (Table 4).

As seen in Table 5, 75.3\% of the migrant smugglers (131 individuals) were unemployed, while $20.7 \%$ (36 individuals) were self-employed. Only $4 \%$ of them ( 7 individuals) reported their original occupation as smugglers. Having asked the reasons for working in "human smuggling business", participants fiercely responded that migrant smuggling was the "Easy way to earn money" (74.7\%; 130 individuals). With regard to learning smuggling as a profession, $69.5 \%$ of the migrant smugglers (121 individuals) reported that they learned it from their friends, while $8 \%$ of them (14 individuals) began smuggling due to their own migration experience.

Table 6 depicts the criminal backgrounds of the smugglers in Turkey. 53.4\% of the human smugglers (93 individuals) had criminal records in Turkey. At this end, 22.4\% (39 individuals) were arrested due to human smuggling, 9.2\% (16 individuals) were arrested for opposition to Turkish Law No. 6136 (Firearms, Knives and Other Similar Objects), and 8\% (14 individuals) were arrested for ordinary crimes. 
Table 2. Relations between illegal migrants and migrant smugglers.

\begin{tabular}{|c|c|c|}
\hline Contact with migrant smugglers & n & $\%$ \\
\hline Through friends & 173 & 66.0 \\
\hline Himself & 33 & 12.6 \\
\hline Through relatives & 56 & 21.4 \\
\hline Total & 262 & 100.0 \\
\hline Amount contracted with migrant smugglers & n & $\%$ \\
\hline$\$ 5000$ or less & 62 & 23.7 \\
\hline$\$ 5001$ or more & 200 & 76.3 \\
\hline Total & 262 & 100.0 \\
\hline $\mathrm{M} \pm \mathrm{SD}$ & \multicolumn{2}{|c|}{$7107.44 \pm 2778.58$} \\
\hline Amount paid to migrant smugglers & $\mathbf{n}$ & $\%$ \\
\hline$\$ 1000$ or less & 24 & 9.2 \\
\hline$\$ 1001$ or more & 238 & 90.8 \\
\hline Total & 262 & 100.0 \\
\hline $\mathrm{M} \pm \mathrm{SD}$ & \multicolumn{2}{|c|}{$3070.03 \pm 1353.18$} \\
\hline Source of money & n & $\%$ \\
\hline Saved money & 88 & 33.6 \\
\hline Money from real estate sold & 59 & 22.5 \\
\hline Relatives in foreign countries & 7 & 2.7 \\
\hline Debt & 68 & 26.0 \\
\hline Family & 15 & 5.7 \\
\hline Relatives in home country & 6 & 2.3 \\
\hline Friends in foreign country & 3 & 1.1 \\
\hline Bank loans & 16 & 6.1 \\
\hline Total & 262 & 100.0 \\
\hline Suggestions by migrant smugglers & $\mathbf{n}$ & $\%$ \\
\hline $\begin{array}{l}\text { They suggested migrants that they should say they } \\
\text { were from Mauritania or Burma }\end{array}$ & 47 & 75.8 \\
\hline $\begin{array}{c}\text { They suggested migrants that they did not know } \\
\text { smugglers }\end{array}$ & 9 & 14.5 \\
\hline $\begin{array}{l}\text { They suggested migrants that they should say they } \\
\text { were from East Turkestan }\end{array}$ & 6 & 9.7 \\
\hline Total & 62 & 100.0 \\
\hline Number of migrant smugglers & $\mathbf{n}$ & $\%$ \\
\hline 1 & 3 & 1.1 \\
\hline 2 & 9 & 3.4 \\
\hline 3 & 35 & 13.4 \\
\hline 4 & 82 & 31.3 \\
\hline 5 & 89 & 34.0 \\
\hline 6 & 31 & 11.8 \\
\hline 7 & 13 & 5.0 \\
\hline Total & 262 & 100.0 \\
\hline
\end{tabular}


Table 3. Relationship between illegal migrants and migrant smugglers 2.

\begin{tabular}{|c|c|c|}
\hline Behaviour of migrant smugglers & $\mathbf{n}$ & $\%$ \\
\hline Expert & 34 & 13.0 \\
\hline In panic & 25 & 9.5 \\
\hline Violent & 83 & 31.7 \\
\hline Aggressive and rude & 94 & 35.9 \\
\hline Well-meant & 25 & 9.5 \\
\hline Undecided & 1 & 0.4 \\
\hline Total & 262 & 100.0 \\
\hline Behaviour of migrant smugglers in the migration & $\mathbf{n}$ & $\%$ \\
\hline Aggressive and rude & 139 & 53.1 \\
\hline Physical violence & 29 & 11.1 \\
\hline No comment & 94 & 35.9 \\
\hline Total & 262 & 100.0 \\
\hline Fear of dying & $\mathbf{n}$ & $\%$ \\
\hline Yes & 249 & 95.0 \\
\hline Smugglers threatened or beat & 113 & 45.4 \\
\hline They thought that they had nothing to lose & 68 & 27.3 \\
\hline To avoid it they paid money & 35 & 14.1 \\
\hline They did not know the way & 29 & 11.6 \\
\hline Both to avoid it they paid money and they did not know the way & 4 & 1.6 \\
\hline No & 13 & 5.0 \\
\hline Person who would find them a job in the foreign country & n & $\%$ \\
\hline Friend & 143 & 54.6 \\
\hline Himself & 42 & 16.0 \\
\hline Relative & 37 & 14.1 \\
\hline Smuggler & 40 & 15.3 \\
\hline Total & 262 & 100.0 \\
\hline
\end{tabular}

Table 4. Findings obtained from migrant smugglers.

\begin{tabular}{ccc}
\hline Age range & n & \% \\
\hline $11-18$ years & 7 & 4 \\
$19-29$ years & 53 & 30.5 \\
$30-39$ years & 72 & 41.4 \\
$40-49$ years & 29 & 16.6 \\
$50+$ years & 13 & 7.5 \\
Total & 174 & 100.0 \\
\hline Marital status & $\mathbf{n}$ & $\mathbf{\%}$ \\
\hline Married & 126 & 72.4 \\
Single & 48 & 27.6 \\
Total & 174 & 100.0 \\
\hline Educational background & $\mathbf{n}$ & $\mathbf{\%}$ \\
\hline Illiterate & 46 & 26.5 \\
Primary school & 113 & 64.9 \\
High school & 15 & 8.6 \\
Total & 174 & 100.0 \\
\hline
\end{tabular}

Personal characteristics of migrant smugglers sampled. 
Table 5. Information about migration motivates.

\begin{tabular}{ccc}
\hline Occupation & $\mathbf{n}$ & $\mathbf{\%}$ \\
\hline Unemployed & 131 & 75.3 \\
Self-employed & 36 & 20.7 \\
Smuggler & 7 & 4 \\
Total & 174 & 100.0 \\
\hline Reasons for smuggling & $\mathbf{n}$ & $\mathbf{\%}$ \\
\hline Easy way to earn money & 130 & 74.7 \\
Additional income & 7 & 4 \\
Unemployment & 33 & 19 \\
Being deceived & 4 & 2,4 \\
Total & 174 & 100.0 \\
\hline Whom they learned smuggling & $\mathbf{n}$ & $\mathbf{\%}$ \\
\hline From his own experience & 14 & 8 \\
Friends & 121 & 69.5 \\
Relatives & 37 & 21.3 \\
Bosses & 2 & 1.2 \\
Total & 174 & 100.0 \\
\hline
\end{tabular}

Table 6. Criminal background of smugglers.

\begin{tabular}{ccc}
\hline Prior criminal record & $\mathbf{n}$ & $\mathbf{\%}$ \\
\hline Yes & 93 & 53.4 \\
No & 81 & 46.6 \\
Total & 174 & 100.0 \\
\hline Criminal type & $\mathbf{n}$ & $\mathbf{\%}$ \\
\hline Migrant smuggling & 39 & 22.4 \\
Narcotic & 6 & 3.4 \\
Opposition to fire-arms law & 16 & 9.2 \\
Ordinary crimes & 14 & 8 \\
Theft and fraud & 10 & 5.7 \\
Sexual offenses & 5 & 2.9 \\
Terrorist offenses & 3 & 1.7 \\
No criminal record & 81 & 46.7 \\
Total & 174 & 100.0 \\
\hline
\end{tabular}

Concerning how the migrant smugglers were arrested, Table 7 provides necessary information. It was found that $30.5 \%$ of the smugglers (53 individuals) were apprehended after their houses were searched by police and $28.2 \%$ (49 individuals) were arrested when their storehouses were similarly raided by security forces. In addition, 24.1\% (42 individuals) were arrested while they were providing logistic support to migrants. There were also some smugglers who were caught in the act. For instance, 9.2\% (16 individuals) were arrested together with illegal migrants in the vehicles, while $8 \%$ (14 individuals) were arrested while driving a vehicle full of illegal migrants. Moreover, 3.4\% (6 individuals) were detained together with illegal migrants while transferring them to departure points.

With regard to the number of people who were arrested with the human smugglers, it was found that respectively $24.7 \%$ (43 individuals) were arrested with 5 to 10 people. 31\% (54 individuals) were arrested with $3-5$ people, $21.8 \%$ (38 individuals) were arrested with 2 people, $7.5 \%$ (13 individuals) were arrested with more than 
10 people and only $14.9 \%$ (26 individuals) were arrested alone.

When asked whether human smuggling and illegal migration are crimes or not, $50 \%$ of the migrant smugglers (87 individuals) stated that it was not a criminal offense. With regard to experience in human smuggling, $77.6 \%$ of them (135 individuals) were found to be in the "business" for more than three years. Concerning nationality of the human smugglers, the following findings were found: 81.6\% (142 individuals) were Turks, $6.3 \%$ Pakistanis (11 individuals), 5.2\% Iraqis (9 individuals), 3.4\% Afghans (6 individuals) and 3.4\% Iranians (6 individuals) (Table 8).

Table 7. Information about smuggling process.

\begin{tabular}{|ccc|}
\hline Type of Arrestment & n & \% \\
\hline Driver & 14 & 8 \\
\hline Companion and escort vehicle & 16 & 9.2 \\
At Their Residences & 53 & 30.5 \\
At The Storehouses & 49 & 28.2 \\
Logistical support & 42 & 24.1 \\
Total & 174 & 100.0 \\
\hline How many people were captured with them & $\mathbf{n}$ & $\mathbf{\%}$ \\
\hline Only himself & 26 & 14.9 \\
2 persons & 38 & 21.8 \\
3 - 5 persons & 54 & 31 \\
5 - 10 persons & 43 & 24.7 \\
$10+$ & 13 & 7.5 \\
Total & 174 & 100.0 \\
\hline
\end{tabular}

Table 8. Smuggling background.

\begin{tabular}{ccc}
\hline Is migrant smuggling a crime & $\mathbf{n}$ & $\mathbf{\%}$ \\
\hline Yes & 51 & 29.3 \\
No & 87 & 50 \\
Undecided & 36 & 20.7 \\
Total & 174 & 100.0 \\
\hline Smuggling experience & $\mathbf{n}$ & $\mathbf{\%}$ \\
\hline 1 year & 15 & 8.6 \\
2 years & 24 & 13.8 \\
3 years & 43 & 24.7 \\
4 years & 47 & 27 \\
5+ years & 45 & 25.9 \\
Total & 174 & 100.0 \\
\hline Nationality & $\mathbf{n}$ & $\mathbf{\%}$ \\
\hline Turkish & 142 & 81.6 \\
Pakistan & 11 & 6.3 \\
Afghan & 6 & 3.4 \\
Iraqi & 9 & 5.2 \\
Iranian & 6 & 3.4 \\
Total & 174 & 100.0 \\
\hline & & \\
\hline
\end{tabular}




\section{Discussion}

According to the current literature, data based only on illegal migrants would not be enough to yield up a complete picture of human smuggling. Although illegal migrants are connected with human smugglers in terms of their social network, their cultural backgrounds are somewhat different (Neske, 2006: p. 130; Webb \& Burrows, 2009: p. 8). Therefore, the data of the study were collected from both groups through direct questions. This helped us to reach a bunch of supplemental and necessary information.

In the current study, it was found that $67.6 \%$ of illegal migrants (177 individuals) described the migrant smugglers as violent, aggressive and rude. The same description was reported by $64.2 \%$ of illegal migrants (168 individuals) for the human smugglers who traveled with them throughout the migration process. It is also significant in the present study that $95 \%$ of illegal migrants (249 individuals) experienced fear of dying during their travel and 45.4\% (113 individuals) of them reported that they could not return due to threats and physical violence of the human smugglers during their journey. These findings suggest that illegal migration is in fact a very dangerous and physically violent process. Unlike Van Liempt \& Doomernik (2006), present study reveals that the relation between the smugglers and the migrants is as violent as a criminal offense.

Most studies conclude that human smugglers do not describe themselves as criminals, but rather as "humanitarian assistants" or "service providers" (Staring, 2003; Zhang et al., 2007; Soudijn \& Kleemans, 2009). The current study's finding that $50 \%$ of human smugglers ( 87 individuals) did not perceive illegal migration as a crime is similar to those previous studies' findings. Moreover human smugglers' description of themselves as a "service provider" also indicates their attempts to legitimate their activity. In addition, there were human smugglers who had been "running the business" for more than three years (77.6\%;135 individuals). Since they were in this activity for a long time, smugglers seemed to internalize the activity and become professionals. At this point, 4\% (7 individuals) described their occupation as "smugglers" as if it was their official profession.

Differential Reinforcement Theory argues that if people have more positive concepts about an act, the potentiality to do this act increases (Siegel, 1989). Sutherland's Differential Combination Theory on the other hand states that migration might be learned through behavior. People may learn illegal migration only through engaging in crime and knowing illegally migrated people (Sever, 2012). Migration can be described as a learnable and teachable fact, not a self-recognized fact from social learning process approach. In this approach, friends may display role model in the learning process. For instance, peer groups may act as an information source or model in migration activities (İçli, 2007: p. 122-123). In a similar vein, the current study revealed that $69.5 \%$ of migrant smugglers (121 individuals) learned migrant smuggling from their friends. Therefore, it can be argued that human smuggling is related to social learning theory and differential combinations theory and that it is committed through learning. Similarly $8 \%$ of human smugglers (14 individuals) reported that they began to take part in this activity due to their own experience of illegal migration indicating the role of learning in this regard. The case was similar for the illegal migrants. More than half of them $(54.6 \% ; 143$ individuals) stated that it was their friends who would find them a job in the host country. This indicates the relevance of social learning theory in migration and migrant smuggling. In addition, $15.3 \%$ of illegal migrants (40 individuals) have underlined that one of the most significant motives for illegal migration was job promises of human smugglers. In a similar way, some illegal migrants $(6.9 \%)$ reported that they saw migration-related newspaper advertisements and these were very influential in their decision to migrate. In other words, human smugglers are making propaganda through promises to find people jobs. On the other hand, the other finding that supports the relevance of social learning theory in migration is that only $9.2 \%$ of illegal migrants decided to migrate themselves, but the remaining majority learned migration from their environment. Another support comes from the finding that $66 \%$ of the illegal migrants contacted human smugglers through their friends and $21.4 \%$ through their relatives.

According to the findings of the current study $41.4 \%$ of human smugglers were from 30 to 39 years old, $72.4 \%$ were married, and $94.1 \%$ had primary or lower education level. Therefore, personal characteristics of the human smugglers detained in Turkey are similar to those reported in previous studies in the literature. Moreover, every three out of four human smugglers arrested in Turkey were found to be unemployed (75.3\%). On the other hand, $20.7 \%$ were self-employed and had ordinary jobs such as waiter or real estate agent. In short, it is safe to argue that human smugglers are ordinary people with ordinary lives. Also parallel to the studies in the contemporary literature, current study reveals that $74.7 \%$ of human smugglers had smuggled migrants to earn easy money. There are supportive findings that the amount of easy money earned from smuggling is attractive. Almost all migrant smugglers $(97.7 \%)$ in the sample reported that they got involved in this "business" to raise their pecuniary benefits. 
Although most of the human smugglers arrested in Istanbul were Turkish citizens (81.6\%), there are also some from neighboring countries which brings us to the idea that migrant smuggling has to be considered as a transboundary and professionally organized activity. Soudijn (2006) explained that majority of human smugglers were arrested on the job. However, in the current study most of them were arrested in safe houses (79.4\%) or in storehouses. At this end, it is clear that Turkish police is capable of effectively uncovering migrant smugglers' safe houses. Considering $63.3 \%$ of the migrant smugglers were arrested with at least three people, it is safe to say that human smugglers work in organized groups.

Based on the data from illegal migrants, it was found that the illegal migrants accompanied by the smugglers walked through mountainous terrains to pass the border lines in the eastern and southeastern regions of Turkey. Although Turkey has $8.333 \mathrm{~km}$. of sea borders, only $14.1 \%$ of the human smugglers preferred the coastal lines to infiltrate their clients through Turkish borders. On the other hand, the land border of Turkey with its neighboring countries is about $2.875 \mathrm{~km}$. long and $85.5 \%$ of the smugglers preferred to pass through these land borders. Most of the illegal migrants came across at least three human smugglers during their travel (95.5\%). This shows that migrant smuggling is a transboundary and organized process, just as some other studies also revealed the necessity of organizational connections rather than individual ventures (Bolz, 1995; Myers, 1996; Kwong, 2001).

There are numerous descriptive studies about financial relationships between illegal migrants and human smugglers ((Kwong (1997); Skeldon (2000); Sobieszczyk (2000); Surtees (2003); Gao, (2004)). Zhang \& Chin (2002) found that human smugglers rate basis is between 1.000 and 70.000 US dollars (the mean amount was 50.000 US dollars). It is also reported that there are human smuggling groups demanding $20.000-40.000$ US dollars (Djajic \& Vinogradova, 2013). The amount varies based on distance, host country and travel type. In the current study migrants were asked to pay high amounts of money to illegally migrate from their homelands to Greece. It was found that $76.3 \%$ of them accepted to pay 5000 US dollars or more. The illegal migrants stated that they signed contracts with the smugglers. Having asked that how they paid the smugglers, it was found that $33.6 \%$ paid with their previously saved money, $22.5 \%$ paid by selling their properties and $26 \%$ did not pay any amount but pledged that they would pay it after working in the host country. The latter finding implies that one fourth of illegal migrants kept their connection with the human smugglers in the post-migration period.

Human smugglers keep themselves updated and well-informed about social and legal regulations of the countries that are within the migration route. Pastore et al. (2006) state that human smugglers are very knowledgeable of laws and regulations on migration and border security. Similarly, in the present study it is found that human smugglers had advised illegal migrants about what to tell the security forces in case they were arrested. For instance, $75.8 \%$ of illegal migrants were advised to tell security forces that they were from Moritania or Myanmar, since these countries do not have official representatives (embassy, consulate etc.) in Turkey. In addition 9.7\% of them were advised to tell that they were from East Turkistan (which is subject to jurisdiction of a different law in Turkey rather than the penal code) due to her consanguineous relations with Turkey. Accordingly, it is safe to say that human smugglers deliberately exploit the judicial system to avoid illegal migrants from being deported.

Some significant studies in the literature reveal that most of the migrant smugglers have criminal records not only on human smuggling but also for other smuggling kinds (Pastore, Monzini, \& Sciortino (2006); İçduygu \& Toktaş (2002)). In the current study it is found that $53.4 \%$ of the migrant smugglers had criminal records. In accordance with these records, it is found that $22.4 \%$ were arrested due to human smuggling previously. This indicates that 79th article of the Turkish Penal Code (No. 5237) which draws up "migrant smuggling" and its correction, is not deterrent enough.

Both some academic studies (Narlı (2006); Çınar (2010); Leman \& Janssens (2006)) and reports of International Organizations (UNODC, 2011) refer to the relation between organized crime groups in smuggling business (migrant, weapon, narcotics, etc.) and terrorist organizations. In the current study, a similar finding was obtained in significant numbers. $27.5 \%$ (48 individuals) of the human smugglers have criminal records on terrorism, narcotic and human smuggling related organized crime offenses.

\section{Conclusion}

Illegal or irregular migration in the contemporary world is one of the most important social problems. In this study, we tried to reach a comprehensive understanding and a generic profile of migrant smugglers. With this regard, data collection from both smugglers as perpetrators and illegal migrants as the object of the smuggling 
process provided us a holistic definition of "smugglers". As a result of the information gathered, migrant smugglers in Turkey could be defined as mostly Turkish, dangerous, physically violent, rude and aggressive in behavior. They make a habit of migrant smuggling to earn their lives (considering the charm of easy money) and may have criminal records at this end. Moreover, they presume "migrant smuggling" as an ordinary job and part of the economy. Migrant smugglers are not simply amateurs that try to benefit from irregular migration. They are very well aware of legislation and regulations on migrant smuggling, irregular migration and border security that they advise their clients (illegal migrant) about exploitable legal loopholes in order to permanently reside or extend their durations of stay in the host country. With regard to learning smuggling as a profession, migrant smugglers generally learn the job from their friends. Therefore, it is possible to argue that migrant smuggling is related to social learning theory and differential combinations theory and it is one of the crimes that is learned. The findings of the study also provide the following information: almost half of the migrant smugglers in Turkey are 30 - 39 years old; three fourths are married and most of them have low levels of education. Coming to the organizational aspects, it must be stated that migrant smugglers constitute a transboundary and organized structure and work in groups to achieve their smuggling activities. They mostly prefer mountainous terrains to pass through border lines in the eastern and southeastern regions of Turkey. Depending on the distance to destination, migration policies of the host country and travel type, migrant smugglers earn an average of $\$ 7107$ per migrant.

\section{References}

Batsyukova, S. (2012). Human Trafficking and Human Smuggling: Similar Nature, Different Concepts. Studies of Changing Societies: Comparative and Interdisciplinary Focus, 1, 39-49.

Bolz, J. (1995). Chinese Organized Crime and Illegal Alien Trafficking: Humans as a Commodity. Asian Affairs, 22, 147158.

Çınar, B. (2010). Human Trafficking in Recruiting Terrorists. Turkish Journal of Politics, 1, 55-69.

Cornelius, W. A. (2005). Controlling “Unwanted” Immigration: Lessons from the United States, 1993-2004. Journal of Ethnic \& Migration Studies, 31, 775-794. http://dx.doi.org/10.1080/13691830500110017

Courau, H. (2003). “Tomorrow Inch Allah, chance!” People Smuggler Networks in Sangatte. Immigrants \& Minorities: Historical Studies in Ethnicity, Migration and Diaspora, 22, 347-387.

Djajic, S., \& Vinogradovay, A. (2013). Undocumented Migrants in Debt. Labour Economics, 21, 15-24. http://dx.doi.org/10.1016/j.labeco.2012.12.004

Gao, Y. (2004). Chinese Migrants and Forced Labour in Europe. In Focus Programme on Promoting the Declaration on Fundamental Principles and Rights at Work. Geneva: ILO.

Hamood, S. (2006). African Transit Migration through Libya to Europe: The Human Cost. Cairo: The American University of Cairo, Forced Migration and Refuge Studies.

Horwood, C. (2009). In Pursuit of the Southern Dream: Victims of Necessity-Assessment of the Irregular Movement of Men from East Africa and the Horn to South Africa. Geneva: International Organization for Migration.

Içduygu, A., \& Toktaş, Ş. (2002). How Do Smuggling and Trafficking Operate via Irregular Border Crossings in the Middle East? Evidence from Fieldwork in Turkey. International Migration, 40, 25-54. http://dx.doi.org/10.1111/1468-2435.00222

İçli, T. G. (2007). Kriminoloji. Ankara: SeçkinYayınları.

International Organisation of Migration (IOM) (2009). Uluslararası Göç Hukuku No. 18: Göç Terimleri Sözlüğü. Cenever: IOM.

Kwong, P. (1997). Forbidden Workers: Illegal Chinese Immigrants and American Labor. New York: New York Press.

Kwong, P. (2001). Impact of Chinese Human Smuggling on the American Labor Market. In D. Kyle, \& R. Koslowski (Eds.), Global Human Smuggling (pp. 235-256). Baltimore, MD: John Hopkins University Press.

Lee, M. (2005). Human Trade and the Criminalization of Irregular Migration. International Journal of the Sociology of Law, 33, 1-15. http://dx.doi.org/10.1016/j.ijsl.2004.09.004

Leman, J., \& Janssens, S. (2006). An Analysis of Some Highly-Structured Networks of Human Smuggling and Trafficking from Albania and Bulgaria to Belgium. Migracijske i etničke teme, 22, 231-245.

Myers, W. (1996). The Emerging Threat of Transnational Organized Crime from the East. Crime, Law and Social Change, 24, 181-222. http://dx.doi.org/10.1007/BF01312206

Narli, N. (2006). Human Trafficking and Smuggling: The Process, the Actors and the Victim Profile. In Trafficking in Persons in South East Europe: A Threat to Human Security (pp. 9-38). Vienna: Austrian Federal Ministry of Defence (BMLV). 
Neske, M. (2006). Human Smuggling to and through Germany. International Migration, 44, 121-163. http://dx.doi.org/10.1111/j.1468-2435.2006.00382.x

Pastore, F., Monzini, P., \& Sciortino, G. (2006). Schengen's Soft Underbelly? Irregular Migration and Human Smuggling across Land and Sea Borders to Italy. International Migration, 44, 95-119. http://dx.doi.org/10.1111/j.1468-2435.2006.00381.x

Roth, M. P. (2010). Global Organized Crime: A Reference Handbook. Santa Barbara, CA: ABC-Clio LLC.

Sever, H. (2012). Sosyal Öğrenme Teorileri Işı̆̆ında Yasadışı Göç ve Etkileri. Dumlupınar Üniversitesi Sosyal Bilimler Dergisi, 32, 51-66.

Siegel, L. J. (1989). Criminology. St. Paul, MN: West Pub Comp.

Skeldon, R. (2000). Myth and Realities of Chinese Irregular Migration. IOM Migration Research Series 1/2000, Geneva: IOM.

Sobieszczyk, T. (2000). Pathways Abroad: Gender and International Migration Recruitment Choices in Northern Thailand. Asian and Pacific Migration Journal, 9, 391-428.

Soudijn, M. R. J. (2006). Chinese Human Smuggling in Transit. Den Haag: Boom Juridische Uitgevers.

Soudijn, M. R. J., \& Kleemans, E. R. (2009). Chinese Organized Crime and Situational Context: Comparing Human Smuggling and Synthetic Drugs Trafficking. Crime, Law and Social Change, 52, 457-474. http://dx.doi.org/10.1007/s10611-009-9203-3

Staring, R. (2003). Smuggling Aliens towards the Netherlands: The Role of Human Smugglers and Transnational Networks. In D. Siegel, H. van de Bunt, \& D. Zaitch (Eds.), Global Organized Crime: Trends and Developments (pp. 105-116). Dordrecht: Kluwer. http://dx.doi.org/10.1007/978-94-007-0985-0 12

Surtees, R. (2003). Female Migration and Tracking in Women: The Indonesian Context. Development, 46, 99-106. http://dx.doi.org/10.1177/10116370030463016

United Nations Office on Drugs and Crime (UNODC) (2010). Smuggling of Migrants into, through and from North Africa: A Thematic Review and Annotated Bibliography of Recent Publications. Vienna: UNODC.

United Nations Office on Drugs and Crime (UNODC) (2011). Smuggling of Migrants: A Global Review and Annotated Bibliography of Recent Publications. Vienna: UNODC.

Van Liempt, I., \& Doomernik, J. (2006). Migrant's Agency in the Smuggling Process: The Perspectives of Smuggled Migrants in the Netherlands. International Migration, 44, 165-190. http://dx.doi.org/10.1111/j.1468-2435.2006.00383.x

Webb, S., \& Burrows, J. (2009). Organised Immigration Crime: A Post-Conviction Study. Research Report, No. 15, London: Home Office. http://rds.homeoffice.gov.uk/rds/pdfs09/horr15c.pdf

Zhang, S. X., Chin, K. L., \& Miller, J. (2007). Women's Participation in Chinese Transnational Human Smuggling: A Gendered Market Perspective. Criminology, 45, 699-733. http://dx.doi.org/10.1111/j.1745-9125.2007.00085.x

Zhang, S., \& Chin, K. L. (2002). The Social Organization of Chinese Human Smuggling: A Cross-National Study. San Diego, CA: San Diego State University.

Zhang, S., \& Chin, K. L. (2004). Characteristics of Chinese Human Smugglers. Washington, DC: US Department of Justice, Office of Justice Programs, National Institute of Justice. 
Scientific Research Publishing (SCIRP) is one of the largest Open Access journal publishers. It is currently publishing more than 200 open access, online, peer-reviewed journals covering a wide range of academic disciplines. SCIRP serves the worldwide academic communities and contributes to the progress and application of science with its publication.

Other selected journals from SCIRP are listed as below. Submit your manuscript to us via either submit@scirp.org or Online Submission Portal.
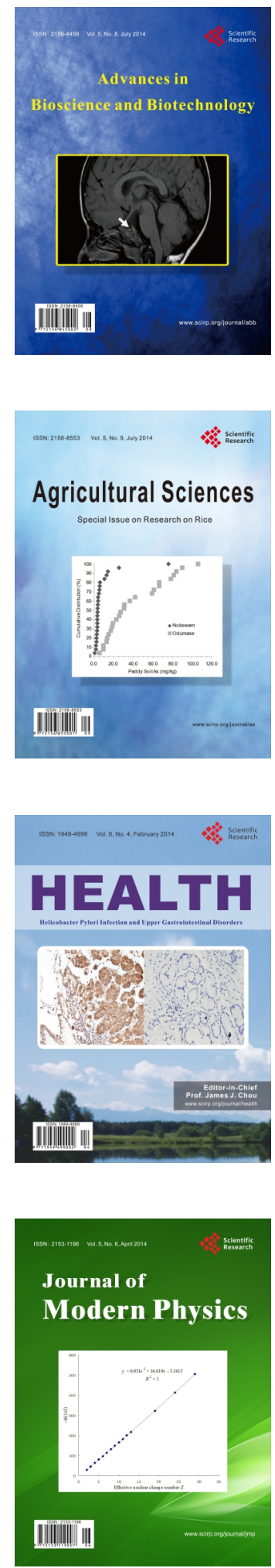
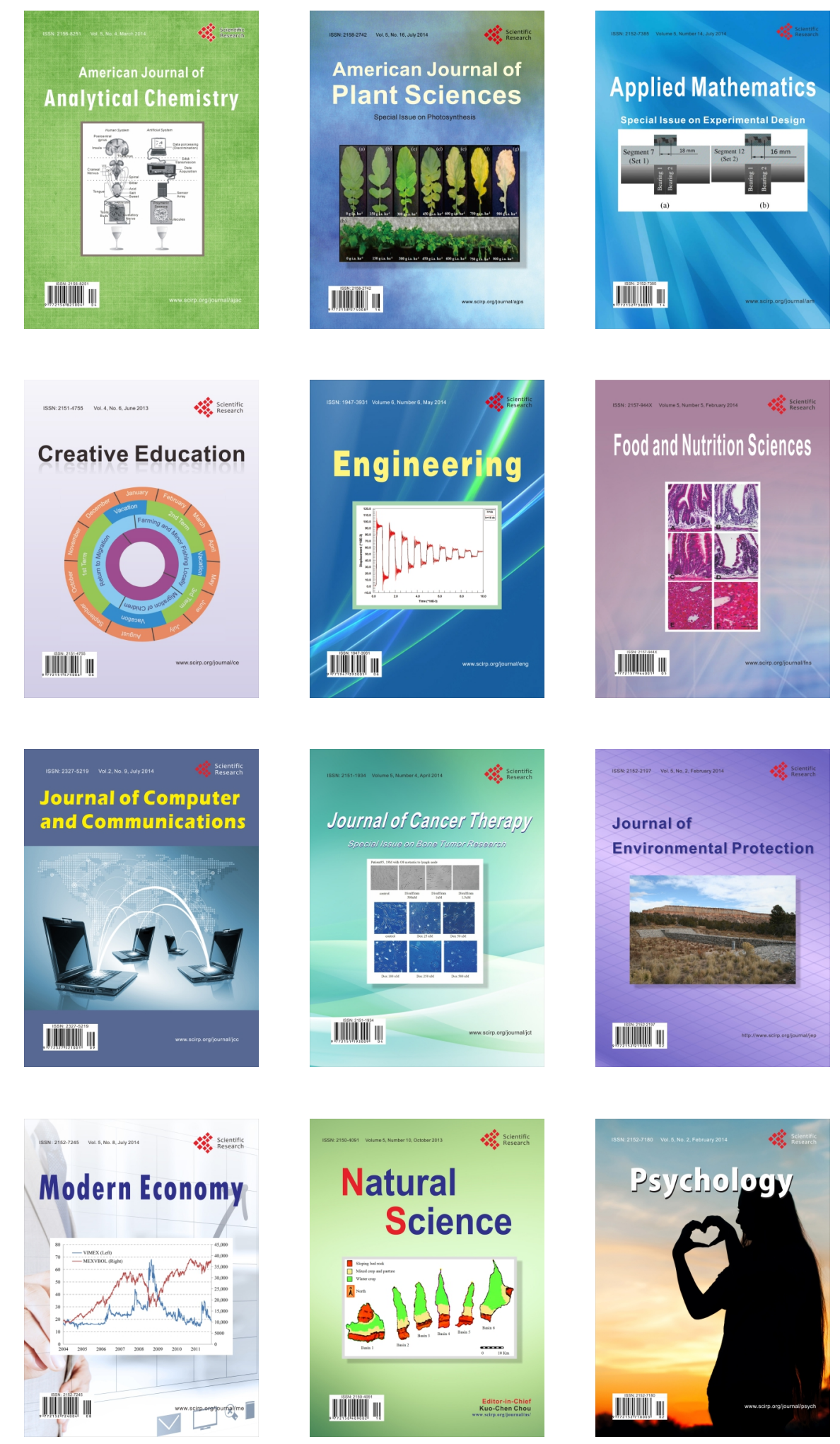